\title{
Postprawda i nowe media. Czy potrzebujemy postprawdy?
}

Streszczenie: Termin postprawda uznany przez redaktorów Oxford Dictionaries za słowo 2016 roku, jeszcze kilka miesięcy temu stanowił modny w kręgach intelektualistów i przedstawicieli nauk społecznych termin lepiej lub gorzej opisujący rzeczywistość załamującego się dość niespodziewanie ładu zachodniego świata. Dziś z powodzeniem wchodzi on do języka potocznego będąc chętnie stosowanym przez publicystów, dziennikarzy, a nawet satyryków. W obliczu tak gwałtownego wzrostu popularności postprawdy, warto zadać pytanie czy politolog w swoim aparacie pojęciowym potrzebuje nowego terminu i czy może wnieść on coś do badań nad rzeczywistością polityczną, szczególnie biorąc pod uwagę wydarzenia takie jak Brexit czy wybór Donalda Trumpa na 45. Prezydenta Stanów Zjednoczonych. Celem artykułu jest więc odpowiedź na pytanie: na ile postprawda tworzy pewną pojęciową autonomię? Drugim natomiast, jest pytanie o dystrybucję treści niezgodnych z prawdą i udział w tym procederze nowych mediów.

Słowa kluczowe: postprawda, nowe media, marketing polityczny

\section{Wstęp}

$\mathbf{L}$ udzie chętnie wyznaczają koniec jakiejś epoki, czy znanych dotychczas prawidłowości rozwoju: koniec historii, koniec polityki, koniec ideologii, postnowoczesność itp. Czasem wynika to z nadziei na istotną zmianę, a czasem - przeciwnie - z obawy przed jej nadejściem. Zaklinamy w ten sposób rzeczywistość lecz czas weryfikuje nasze oceny i pokazuje, że „koniec” wciąż przed nami. Być może dotyczy to także postprawdy?

Postprawda opisuje rzeczywistość, w której fakty nie mają znaczenia. To chyba najprostsza charakterystyka terminu, który w 2016 roku stał się niezwykle popularny w opisie rzeczywistości, szczególnie w obszarze polityki. W dyskursie publicznym pojawił się on jednak już wcześniej - pierwotnie użyty przez amerykańsko-serbskiego dramaturga Stevea Te- 
sicha w 1992 r. w magazynie „Nation” (Flood, 2016), później spopularyzowany dzięki książce Ralpha Keyesa z 2004 roku zatytułowanej The Post-Truth Era: Dishonesty and Deception in Contemporary Life. Co ciekawe, R. Keyes pisząc o postprawdzie uznał, iż kariera tego terminu rozpoczęła się już wraz z pojawieniem się telewizji (lata 50. XX wie$\mathrm{ku}$ ), która wprowadziła zupełnie nowe formy komunikowania politycznego, w głównej mierze oparte na przekazie komunikatów do odbiorcy torem peryferyjnym, skłaniając go do podejmowania decyzji na zasadzie heurezy, a nie racjonalnej analizy dostarczanych przez polityków argumentów. Po 70 latach sama telewizja pozostaje istotnym dystrybutorem postprawdy (Festinger, 1957), choć rozszerzająca się w ostatnich latach typologia masowych kanałów komunikacji wiele w tej materii zmieniła. Bez wattpienia jednak, u podstaw rozpatrywanego terminu leżą szeroko pojęte media masowe zniekształcające, upraszczające bądź też zmieniające rzeczywistość społeczną, pełniąc rolę pośrednika w akcie komunikacyjnym.

Jeśli przyjmiemy, że stwierdzenie, iż „fakty nie mają znaczenia” staje się coraz bardziej użyteczne, można zadać sobie pytanie, co je zastępuje? Co ma znaczenie? Nieprawda? Kłamstwo? Wyobrażenie? A może pragnienie widzenia świata w sposób zgodny ze swoimi poglądami (życzeniowość), co wyjaśniał już w teorii dysonansu poznawczego Leon Festinger (1957). W sensie językowym określenie postprawda brzmi nowo, ale jego odzwierciedlenie w rzeczywistości jest znane od bardzo dawna. Warto spróbować zatem zastanowić się, co nowego - w wymiarze eksplanacyjnym - wnosi do opisu polityki?

Przyjmujemy na wstępie hipotezę, że nowym nie jest zjawisko postprawdy, lecz forma dystrybuowania tego rodzaju opisu rzeczywistości, którą w ostatnich kilku latach przyniósł rozwój nowych mediów. Wydaje się bowiem, iż doniosłe zmiany dotykające masowego komunikowania w ostatnich dziesięcioleciach (m.in. redundancja, uspołecznienie, komercjalizacja, dywersyfikacja, dynamizacja przekazu itd.) sprzyjają intensyfikacji występowania samego zjawiska, ale i pewnej systematyczności w stosowaniu postprawdy (jako narzędzia) przez polityków dla osiągnięcia określonych, partykularnych celów. Nie bez znaczenia pozostaje też coraz bardziej skomplikowany świat samych mediów, wraz z jego zawiłym systemem dystrybucji treści, personalizacji komunikatów, ale i szerzej nierozumianymi językami programowania czy infrastrukturą sieciowa. Wszystko to sprawia, iż osobista diagnoza zastanej rzeczywistości uniemożliwia w wielu przypadkach odpowiedź na - zdawałoby się 
- podstawowe i kluczowe pytanie związane z korzystaniem z mediów: na ile docierające do nas wiadomości są zbieżne z prawda, a na ile stanowią „odnoszące się do, lub opisujące sytuację, w której obiektywne fakty mają mniejsze znaczenie w kształtowaniu opinii publicznej, niż odwołania do emocji i osobistych przekonań"1.

\section{Postprawda a kłamstwo}

Postprawdę uznaje się niejednokrotnie po prostu za kłamstwo ${ }^{2}$. Zasadnym jest więc pytanie, czy termin ten cokolwiek wnosi do opisu rzeczywistości, skoro w swoim braku logiki wydaje się być - jak pisze Kathleen Higgins - „nienaturalny” (2016). Dlaczego w takim razie poczuliśmy potrzebę wprowadzenia i wykorzystywania nowego terminu dla opisywania rzeczywistości, która w swej istocie nie zmieniła się tak mocno? Czyżby politycy dopiero teraz zaczęli posługiwać się kłamstwem dla realizacji swoich celów? Czy demokratyczna polityka (a tym bardziej ta realizowana w systemach niealternatywnych) nie była od niepamiętnych czasów skażona demagogia, odwoływaniem się do emocji, wykorzystywaniem mitycznych struktur poznawczych, stereotypów i uprzedzeń wyborców?

Łukasz Pawłowski zadaje w „Kulturze Liberalnej” pytanie: Czym różni się postprawda od „zwykłego” kłamstwa? Jego zdaniem „,różnica na poziomie indywidualnym polega na tym, że o ile tradycyjny kłamca mówi nieprawdę po to, by odwrócić naszą uwagę od faktów - np. polityk przekonujący, że popiera podwyżkę podatków dla najbogatszych, choć głosował za ich obniżeniem - o tyle dla kłamcy współczesnego owe fakty nie mają żadnego znaczenia - jednego dnia powie nam, że podatki należy podnieść, drugiego, że obniżyć, a trzeciego, że jeszcze nigdy się nad tym nie zastanawiał i musi pomyśleć. Dla kłamcy tradycyjnego fakty są więc punktem odniesienia. Dla kłamcy epoki postprawdy nie mają one żadnego znaczenia" (Pawłowski, 2016). Do tej konstatacji należy dodać uwagę, iż rozwój nowoczesnych środków masowego przekazu spowodował, że współczesna polityka jest w znacznie większym stopniu oparta na szumie informacyjnym, w którym zacierają się granice między faktem a opinia, prawdą i fałszem, informacją i dezinformacją. W tych realiach

1 Najbardziej spopularyzowana definicja: Post-truth, https://www.oxforddictionaries.com/press/news/2016/12/11/WOTY-16.

2 Steward Lockie określa postprawdę wręcz „bezwarunkowym kłamstwem” (2017). 
nawet wielokrotnie zdementowane informacje długo mogą żyć własnym życiem. Co więcej - mogą tworzyć kolejne wersje obrazów nieistniejącej rzeczywistości, czasem już bardzo odległe od pierwotnych inspiracji ${ }^{3}$. Powstaje złożone wyobrażenie świata oparte na informacjach, których wspólną cechą jest ich nieprawdziwość. W tym fałszywie postrzeganym świecie politycy nie rywalizują ze sobą $\mathrm{w}$ diagnozie realnie istniejących problemów, bowiem - zgodnie z zasadami postprawdy - fakty nie mają znaczenia. W tej rzeczywistości liczy się to, aby jak najsilniej zmobilizować emocje pozytywne wokół siebie i negatywne wobec rywali. Prawda nie zawsze jest tak silnym generatorem emocji, jak wytworzone intencjonalnie kłamstwo. Możemy zatem mówić o tzw. kłamstwie społecznym, którego analizie wiele miejsca w swoich publikacjach poświęcił Wojciech Chudy (Chudy, 2003, s. 212-218).

Przyjrzyjmy się skutkom kłamstwa społecznego w kontekście postprawdy. Odwołując się do rozważań W. Chudego, możemy wyróżnić sześć jego skutków (Filipowicz, 2016, s. 65-67). Spróbujmy je zredefiniować i uzupełnić, odnosząc się do zjawiska postprawdy.

Po pierwsze, kłamstwo oznacza odebranie człowiekowi wolności decyzji, a w konsekwencji, poznawcze ubezwłasnowolnienie osoby okłamywanej. Rozwiązywanie problemu decyzyjnego, np. dokonanie politycznego wyboru, odbywa się w warunkach celowej dezinformacji, odbierającej możliwość podjęcia decyzji racjonalnej metodologicznie. Co więcej, bronią w walce z postprawda nie jest prawda. Może być ona bowiem mało przekonująca.

Po drugie, skutkiem kłamstwa w wymiarze społecznym jest atmosfera nieufności prowadząca do atomizacji społeczeństwa lub jego polaryzacji. Ludzie zaczynają się dzielić według kryterium pojmowania prawdy i wiary (lub nie) w kłamstwa. Żyją w innych - często przeciwstawnych - rzeczywistościach, których wiarygodność potwierdzają informacje pochodzące ze środków masowego przekazu tworzących obraz świata, zgodny z oczekiwaniami danego odbiorcy. Stąd, ubocznym skutkiem postprawdy może być pogłębienie podziałów psychopolitycznych działających konfliktogennie, a przez to - destrukcyjnie w obszarze publicznej debaty czy szerzej - relacji demokratycznych.

Trzecim skutkiem jest postępująca komercjalizacja demokracji; wynika ona $\mathrm{z}$ faktu podporządkowania prawdy społecznej zasadzie maksy-

3 Zbliża to analizowane tu prawidłowości do tradycyjnego mechanizmu plotki (Jeran, 2008, s. 269). 
malizacji zysku i prawom rynku. Zjawisko postprawdy jeszcze silniej pokazuje, iż współcześnie w swych decyzjach jednostka powinna kierować się egoistycznie pojmowanym pojęciem interesu, odrzucając te wizje rzeczywistości, które realizację owego interesu utrudniają, uniemożliwiają czy delegitymizują. Zgodność z wcześniej ukształtowanymi poglądami, a także oczekiwania zaspokojenia określonych potrzeb wyznaczają pożądany obraz świata stworzony na bazie postprawdy. Być może prawda jest jedna, lecz postprawd z pewnością może być wiele. Wybieramy tę najbardziej użyteczną dla nas, co paradoksalnie wpisuje się w teorię racjonalnego wyboru.

Kolejnym następstwem postprawdy jest naruszenie podstawowych zasad komunikacji społecznej. Pozwala ona istnieć wspólnocie i w pewnej mierze ją tworzy, lecz kiedy społeczeństwo doświadczy kłamstwa, wówczas dochodzi do zaburzenia komunikacji, a tym samym do rozpadu tejże wspólnoty. Należy jednak zauważyć, iż postprawda także kreuje nowe wspólnoty w obrębie rozpadającej się, dotychczasowej wspólnoty wyższego rzędu np. narodu. A zatem, choć komunikowanie służące dezinformacji jest $\mathrm{w}$ istocie rzeczy manipulacją, może prowadzić do łączenia się ludzi na bazie fałszywych obrazów świata. Co więcej, obrona tej wizji miewa charakter integrujący i przeradzający się w „syndrom oblężonej twierdzy", co nierzadko przeradza się w ruchy społeczne, a nawet w ich zinstytucjonalizowane formy.

Po piąte, każdy człowiek ma prawo do poznawania prawdy, a poprzez kłamstwo to prawo zostaje złamane (Chudy, 1990, s. 398). Kłamstwo prowadzi do zniewolenia drugiego człowieka i swoistej dominacji nad okłamywanym. Język potoczny z często stosowaną frazą ,prawda jest taka..." pokazuje z jaką łatwością jesteśmy skłonni narzucać innym swoją wizję świata, czując się depozytariuszami prawdy i uprzedmiotowiając odbiorcę komunikatu. Obraz świata, jaki znamy jest w głównej mierze efektem kontaktu ze środkami masowego przekazu. Internet to zjawisko spotęgował. Możliwość zweryfikowania obrazu rzeczywistości kształtowanego przez mass media jest dla przeciętnego człowieka bardzo ograniczona. Kiedyś ludzie wiedzieli o świecie zdecydowanie mniej, lecz to, co wiedzieli wynikało z ich bezpośredniego poznania i doświadczenia. Nie gwarantowało to wiedzy prawdziwej, ale utrudniało wpływ obcych osób na postrzeganie prawdy.

Jako ostatni skutek postprawdy można podać agresję (Chudy, 2003a, s. 55-56). Jest to agresja zarówno ze strony kłamcy, jak i okłamywanego, szczególnie silna w momencie zdemaskowania kłamstwa. Zachowania 
agresywne są wywołane u kłamcy poprzez odczuwany lęk przed zdemaskowaniem kłamstwa i jego konsekwencjami. Natomiast zachowania agresywne u okłamanego powstają w chwili odkrycia faktu bycia okłamanym. Mogą one prowadzić do zemsty i pragnienia wzięcia odwetu. Jednocześnie jednak, w okłamanym dochodzi do zachwiania poczucia własnej wartości. Odkrycie kłamstwa powoduje u niego wewnętrzną sprzeczność - może nie chcieć poznać prawdy, bo ta zburzy wygodny obraz świata, w którym złymi, niszczącymi podstawowe wartości, są „oni”, a „my” tych wartości bronimy, stojąc na gruncie prawdy. Stąd też znamiennym wydaje się w warunkach dominacji postprawdy w opisie rzeczywistości, niechęć do tych ekspertów, którzy mogą objawiać „niewygodne prawdy”. Każda wspólnota zjednoczona na bazie postprawdy musi mieć swoich, „obiektywnych” ekspertów.

Warto także zauważyć, iż wizja świata ukształtowana przez postprawdę może stanowić podstawę samookłamywania się. Jest to działanie, w trakcie którego człowiek ,wprowadza siebie w stan przekonania sprzecznego w stosunku do uprzedniego rozpoznania rzeczywistości lub w stosunku do poznania dostępnego jej na drodze obiektywnego uzasadnienia" (Chudy, 2003b, s. 628-629). Samookłamywanie się stanowi działanie w obszarze własnych emocji, wyborów i poznania intelektualnego, „wskutek którego asercja prawdy odnosząca się do przedmiotu, będącego celem fałszującego działania autokłamstwa, zostaje osłabiona, a następnie zanegowana" (Ibidem, s. 629). Postprawda ułatwia racjonalizację własnych ,wygodnych” poglądów i ocen.

Możemy zatem uznać, iż postprawda jest nową formułą dobrze znanego kłamstwa społecznego. Jest odpowiedzią na zapotrzebowanie licznej rzeszy ludzi, którzy szukają przede wszystkim potwierdzenia własnych emocji i życzeniowego postrzegania świata. Nowe media, które mogłyby służyć przede wszystkim poznaniu, poszerzają przepaść między wiedzą faktyczną a obrazem rzeczywistości stymulującym gotowość do podejmowania decyzji w wielu sferach życia społecznego, a zwłaszcza w polityce. Postprawda dystrybuowana przez nowe media tworzy wspólnoty oparte na fałszywym wyobrażeniu świata i lęku, iż mogłoby ono zostać zakwestionowane.

\section{Postprawda jako instrument marketingu politycznego}

Marketing polityczny, w jeszcze większym stopniu niż komercyjny, naznaczony jest negatywną konotacją. Wyrażany często u jego po- 
czątków pogląd, iż polityka (politykę) sprzedaje się podobnie jak każdy towar konsumpcyjny wskazywał, iż istota produktu jest zdecydowanie mniej ważna niż jego cechy zewnętrzne, wizerunkowe. Te z kolei, można dowolnie kształtować w zależności od potrzeb rynku politycznego. Marketing polityczny $\mathrm{w}$ zasadzie nigdy nie był traktowany neutralnie, co potwierdza zresztą potoczna opinia o tych, którzy go uprawiają - spin doctorach. Nakłanianie wyborców do popierania określonych opcji politycznych stało się w warunkach demokracji liberalnej płaszczyzną marketingowych sztuczek. Nowe media stworzyły jeszcze skuteczniejsze środki ich urzeczywistniania. A to prowadzi nas do postprawdy.

Negatywna ocena marketingu politycznego wynika m.in. z faktu, iż dla potrzeb wizerunkowych specjaliści od jego kreowania nierzadko posuwają się - zwłaszcza w okresie kampanii wyborczych - do kłamstwa. Edmund Wnuk-Lipiński wyróżnił dwa rodzaje kłamstw wyborczych: mobilizacyjne i demobilizacyjne (1992, s. 52). Zadaniem pierwszych jest pozyskanie zwolenników danego produktu politycznego i ukształtowaniu wobec niego pozytywnych emocji (obietnice bez pokrycia). Drugie, służy dyskredytacji wizerunku przeciwnika i spowodowanie wyzwolenia wobec niego negatywnych emocji wyborców (bezpodstawne oskarżenia). Postprawda obejmuje oba kłamstwa, co pokazuje, że jako narzędzie marketingowe nie jest jakościowo niczym nowym. W ostatnim czasie zmieniła się jednak skala zastosowania tego narzędzia, co wydaje się mieć związek z wykorzystaniem internetu (a zwłaszcza portali społecznościowych) w komunikacji politycznej.

Dlaczego osoby publiczne tak często obecnie kłamią? Czy dlatego, iż w erze postprawdy zdemaskowanie kłamstwa nie jest możliwe? A może obnażenie kłamstwa nie ma znaczenia, bo każdy ma swoją (post)prawdę? Kampanie wyborcze w krajach demokratycznych zawsze były okresem, w którym dla potrzeb marketingowych politycy mogli bezkarnie ukrywać prawdę czy też podawać informacje nieprawdziwe. Przez wiele lat dla zamaskowania kłamstw polityków w okresie wyborów wykorzystywaliśmy określenie „obietnice wyborcze” (eufemizm). Wiedzieliśmy zatem, iż politycy zwłaszcza w okresie wyborczym „mijają się z prawdą” (eufemizm), lecz akceptowaliśmy obietnice wyborcze, bowiem akceptacja nierealnej obietnicy w mniejszym stopniu narusza nasze poczucie godności niż zgoda na kłamstwo. Człowieka, który poważnie traktowałby polityczne wypowiedzi i ekonomiczne przyrzeczenia okresu wyborczego należałoby traktować jako naiwnego (Pawełczyk, 2000, s. 56). 
Wydaje się, że nowa jakość postprawdy polega na tym, że jest to kłamstwo nie tylko incydentalnie wprowadzające w błąd, lecz konstruujące całkowicie nową rzeczywistość. Nie jest to już kłamstwo służące celom doraźnym, po których osiagnnięciu wraca się do prawdziwej rzeczywistości. Obraz świata dany w postprawdzie nie przemija i nie daje się zdementować, bowiem - o czym pisaliśmy wcześniej - raz uwierzywszy w kłamstwo uciekamy od dysonansu poznawczego. Możemy zatem rozumieć postprawdę w znaczeniu kłamstwa zorganizowanego, które zdaniem Hanny Arendt było specyficzne dla systemów totalitarnych (Arendt, 1985). Tym razem pojawia się ono jednak jako instrument marketingu politycznego i to zarówno w systemach, które uznawaliśmy do tej pory jako demokracje skonsolidowane, jak i tych, które - jak się wydawało - zamierzają tą drogą pójść. Można więc przyjąć, iż rosnący populizm w kulturze Zachodu i towarzysząca mu postprawda, nie są tylko efektem zmęczenia dotychczasową formą demokracji, bowiem zjawisko postprawdy zaczęło się objawiać zarówno w krajach, w których ustrój ten funkcjonuje 200 lat, jak i tych w których trwa 20 lat. Uważamy, iż postprawda wiąże się przede wszystkim z nowymi środkami komunikowania, które objawiły swoją moc kreowania obrazów rzeczywistości w różnych państwach właściwie w tym samym czasie. Specyfika mediów społecznościowych powoduje, że implementowane tam informacje zaczynają żyć własnym życiem, generując szereg komentarzy, komentarzy do komentarzy itd. W konsekwencji, trudno jest znaleźć pierwotnego nadawcę, odpowiedzialnego za treść komunikatu. Ten brak odpowiedzialności oraz pozorna anonimowość powodują, że można tworzyć alternatywne wizje rzeczywistości, do których będą odnosiły się np. zindywidualizowane przekazy marketingowe, selektywnie adresowane, zgodnie z algorytmem naszej aktywności w sieci.

Politycy w systemach demokracji liberalnej wielokrotnie okłamywali opinię publiczną. O politykach w systemach tylko podających się za demokratyczne nie warto w ogóle wspominać, bowiem kłamstwo może być w nich najłagodniejszą formą mobilizacji poparcia. Wydaje się, iż różnica w kłamstwach współczesnych polityków polega nie tylko na tym, że przyłapani na kłamstwie albo twierdzą, że nigdy nic takiego nie powiedzieli, że zostali źle zrozumiani, lub że nie mówili dosłownie. Ważniejszym jest fakt, iż nowe media pozwalają współcześnie utkać z fałszywych informacji o świecie jego całkowicie alternatywne obrazy, dostosowane do oczekiwań mocno zindywidu- 
alizowanych odbiorców. Stały się one - jak pokazały doświadczenia ostatnich lat - niezwykle efektywnym środkiem w rękach specjalistów od marketingu politycznego.

\section{Nowe media jako narzędzie dystrybucji postprawdy}

Internet, mimo powszechnej zgody medioznawców co do jego obecności w głównym nurcie badań nad środkami masowego komunikowania, po ponad 20 latach od jego skomercjalizowania, bywa ustawiany w opozycji do mediów głównego nurtu4. Dzieje się tak przede wszystkim ze względu na szereg odmienności natury prawnej, organizacyjnej i strukturalnej wciąż wyznaczających oś podziału: media tradycyjne vs. media alternatywne (nowe). Wśród czynników najbardziej ugruntowujących ten podział można wymienić m.in.: mniejszy zakres kontroli prawnej publikowanych treści w sieci, alternatywne zasady ustanawiania agendy, znikomy stopień stosowania zasad politycznej poprawności, dużą liczbę nowych gatunków medialnych czy nadmiar i inflację informacji.

Wrażenie to wzmacnia się na płaszczyźnie komunikacji politycznej, gdzie obserwowana jest wyraźna odmienność między strategiami i stylami komunikacyjnymi podmiotów politycznych w tradycyjnych i nowych mediach. Mniejsza kontrola skutkująca większą swobodą w wyrażaniu opinii i sądów, szerszy repertuar stylów i zabiegów retorycznych, ale i różnorodność form komunikacji sprawiaja, iż internet stanowi środowisko jeszcze bardziej potęgujące logikę mediów tradycyjnych, która opiera się na zasadzie popularyzacji skrajności dla zwiększenia zysku instytucji medialnej (Kreft, 2016). Stanowi to podstawę dla takich zjawisk jak: polityczna agresja, skandalizacja, tabloidyzacja czy swoisty medialny ekshibicjonizm.

Praktyka medialnego życia politycznego mierzona popularnością poszczególnych aktorów w serwisach społecznościowych wskazuje, iż jednostki posługujące się strategiami stanowiącymi zabiegi marginalne w mediach tradycyjnych, tutaj zyskują notowania niewspółmierne do tych wyrażonych chociażby w akcie wyborczym. Prawidłowość tą obrazuje wykres 1.

${ }^{4}$ Nomenklatura ta ugruntowała się także na płaszczyźnie komunikacji politycznej (zob. du Vall, Walecka-Rynduch, 2010). 
Wykres 1. Liczba obserwujących profile liderów politycznych w serwisie Facebook

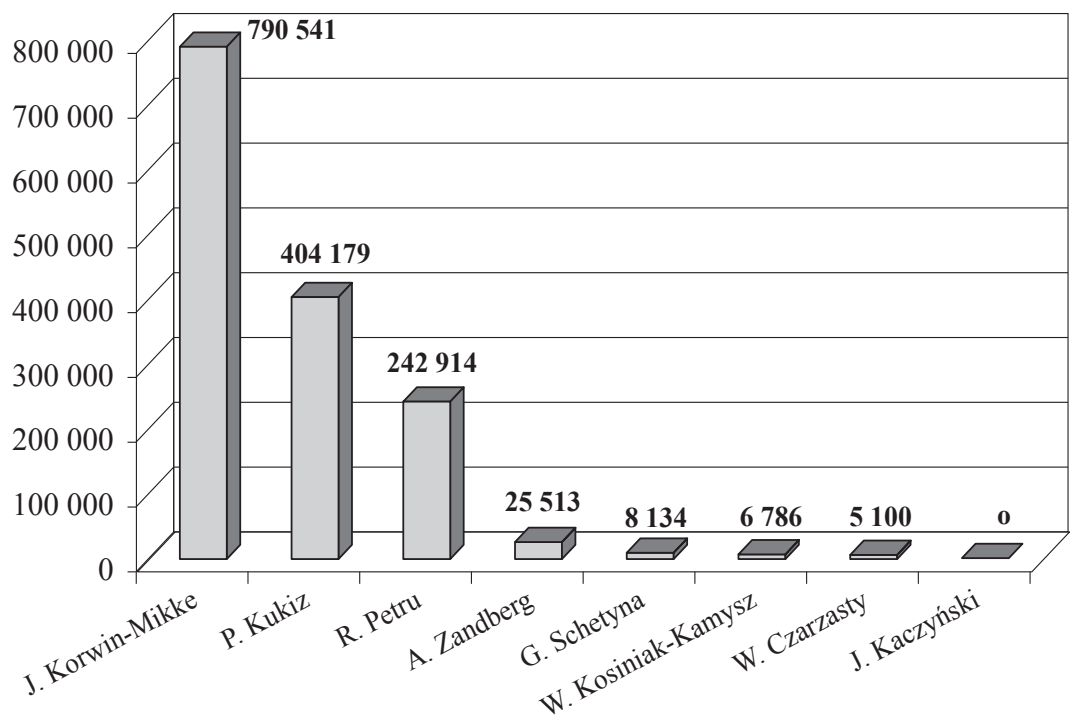

Źródło: Facebook, 20.01.2017 r.

Zjawisko postprawdy dobrze wpisuje się w strategie komunikacyjne polityków skrajnych i uznać można, iż stanowi ważne uzupełnienie ich kanonu działań mających doprowadzić do realizacji partykularnych celów, co zdaje się jednocześnie współgrać z sekwencyjnością poczynań marketingowych w obszarze polityki. Wydaje się też, że nie bez przyczyny termin ten w pełni zmaterializował się w drugiej dekadzie kolejnego stulecia, w czasie dynamicznych przeobrażeń medialnych i szybkiego rozwoju internetu. Takie czynniki jak uspołecznienie sieci, rzekome upodmiotowienie użytkownika-nadawcy, rosnące wskaźniki korzystania z nowych mediów, popularność serwisów społecznościowych, a także nadmiar i inflacja informacji spowodowały, że odróżnienie wiarygodnych danych od fałszywych jest niemal niemożliwe, tym bardziej, kiedy prawdziwość przestaje być kryterium ich poszukiwania. Fakt ten dodatkowo wzmacniają nowe trendy i gatunki, takie jak komunikacja memetyczna, silnie oparta o ironię wymagającą wiedzy i znajomości politycznego kontekstu (Juza, 2013, s. 52). Sprawia to, iż jednym z silniejszych bodźców służących rozwojowi postprawdy są problemy z dekodowaniem informacji. Zjawisko takie można nazwać „miękkim” obliczem postprawdy, które, 
mimo podobnych konsekwencji skutkujących dezinformacją, wydaje się mniej „niebezpieczne” na poziomie intencjonalnego sprawstwa.

W kontekście wspomnianych działań marketingowych, warto więcej uwagi poświęcić „twardej” postprawdzie, a więc tej zdeterminowanej nie interpretacja, a zamierzeniem po stronie nadawcy. Jeśli bowiem mowa o intencjonalnym jej wykorzystaniu dla osiągnięcia celów np. o charakterze wyborczym, to możliwym jest wpisanie jej w sekwencje działań marketingowych. To jednak wciąż nie może stanowić podstawy do mówienia o zjawisku jakościowo nowym, biorąc pod uwagę niebędące na pierwszym planie, ale obecne w demokracji wspomniane przez nas przypadki dezinformacji, pomówień, manipulacji faktami czy zwykłego kłamstwa.

Swojego rodzaju nowością zdaje się jednak być systemowo usankcjonowany mariaż nieprawdy i jej strategicznej, intencjonalnej dystrybucji za pomocą mediów. Zjawisku temu towarzyszy wpisanie postpraw$d y$ w klasyczną sekwencję działań marketingowych z uwzględnieniem segmentacji beneficjentów dezinformacji i jej targetowania. Warto więc zadać pytanie: czy tej aktywności nie należy uznać za swoiste „poczynienie kolejnego kroku" i uznać postprawdę nie jako zabieg w obszarze komunikacji, a jako stały element strategii politycznej?

Wszystko wskazuje na to, że obecności wspomnianych działań możemy doszukać się, badając funkcjonowanie narzędzi analitycznych i polityki informacyjnej w trakcie co najmniej kilku wydarzeń politycznych w 2016 r. Wśród nich najbardziej symptomatyczne dla całej kategorii aktywności obejmujących zagadnienie postprawdy były wybory prezydenckie w USA i sekwencja działań promocyjnych kandydatury Donalda Trumpa w obszarze internetu. Można ją opisać następującą kolejnością zdarzeń ${ }^{5}$ :

1) przeprowadzenie analizy wielkiej ilości danych (big data) w oparciu o aktywność ludzi w sieciach społecznościowych;

${ }_{5}$ Niniejsza metodologia działań promocyjnych opracowana została dla sztabu Donalda Trumpa przez brytyjsko-amerykańską agencję Cambridge Analytica. Firma korzysta z prac Michała Kosińskiego - psychologa społecznego polskiego pochodzenia, który opracował algorytm pozwalający tworzyć modele konsumenckie i diagnozować profile osobowościowe ludzi na podstawie danych pozyskiwanych z serwisów społecznościowych oraz ze smartfonów. Mechanizm ten był wykorzystywany w działaniach promocyjnych Donalda Trumpa zarówno w kampanii bezpośredniej (wolontariusze posiadali aplikację na smartfony, która pozwalała na zapoznanie się z profilem mieszkańca danego domu przed rozmową z nim), jak i pośredniej, w formie np. reklamy w social media (Stone). 
2) tworzenie profilu wyborców przy pomocy odpowiedniego algorytmu, z wykorzystaniem zebranych danych i wnioskując na podstawie ich aktywności sieciowej: jakie mają poglądy polityczne; na kogo są skłonni oddać głos; czy warto wobec nich zastosować strategię zmiany nastawienia, utwardzania czy inną itp.;

3) zdiagnozowanie lokalnego bądź osobistego problemu (lub ogólnego zagadnienia, istotnego z punktu widzenia podjęcia decyzji wyborczej przez jednostkę);

4) przesłanie jednostce komunikatu (np. reklamy w serwisie Facebook), która wykorzystuje wcześniej zdobytą wiedzę i stworzony profil wyborcy. W ten sposób każdy użytkownik sieci społecznościowej otrzymuje indywidualnie dobraną treść, z uwzględnieniem założenia, iż nie musi być ona w pełni zbieżna $\mathrm{z}$ faktami. Ważne zaś, aby była skuteczna.

Przyjęte w ten sposób podejście do marketingu politycznego wydaje się rewolucyjne przynajmniej z kilku powodów. Po pierwsze, odrzucony zostaje, bądź mocno zmodyfikowany paradygmat segmentacyjny, który nakazywał dzielić ogół elektoratu na grupy posiadające określony zbiór cech w celu dostosowania komunikatów do tychże kategorii (Cichosz, Skrzypiński, 2014). Obecna wiedza na temat każdego wyborcy z osobna determinuje nadawcę do możliwie największego poziomu indywidualizacji przekazu, aż do stadium pojedynczej jednostki. Mechanizm ten, już od wielu lat stosowany z powodzeniem w marketingu komercyjnym (Borudsiak, Pierański, Romanowski, Strykowski, 2015, s. 36-43), zaczyna więc być wykorzystywany także w obszarze polityki. Sprawia to, iż każdy odbiorca stanowi właściwie osobny segment w procesie dywersyfikacji komunikatu. Wydaje się, iż w ten sposób, w historii nowocześnie rozumianego marketingu politycznego (począwszy od lat 50. XX wieku, kiedy znacznie istotniejsza była jeszcze lojalność partyjna), wchodzimy w kolejną fazę doskonalenia narzędzi, począwszy od catch all przez segmentation aż do individuation ${ }^{6}$.

Po drugie, na plan dalszy w praktyce marketingu politycznego zdaje się schodzić postulowany w warunkach demokratycznych (a przynajmniej w opisujących je modelach idealnych) dylemat odwołania się do faktów. W erze postprawdy, wyżej od niej w hierarchii wartości znajduje się skuteczność działań, co nie może być uznane za typowe dla współczesnej polityki, lecz - jak wskazywał Machiavelli - dla polity-

${ }^{6} \mathrm{~W}$ pewien przewrotny sposób można by to zjawisko nazwać wręcz powrotem do pierwotnych tradycji elekcyjnych klasycznej demokracji, gdzie pozyskanie głosu wymagało zaangażowania i indywidualnego kontaktu z przedstawicielami »ludu«. 
ki w ogóle ${ }^{7}$ Internet, z całym bagażem prawnych niedomówień, braku kontroli i wzmocnieniem logiki medialnej, jest doskonałym narzędziem do realizacji celów, których miarą jest skuteczność. Wydaje się wiec, iż zagrożenia związane z manipulowaniem faktami, którym zachodnie demokracje próbowały zapobiec przy pomocy prawa na fali sprzeciwu wobec dwudziestowiecznych totalitaryzmów, dziś ujawniają się na nowo $\mathrm{w}$ formie sieci przepełnionej niezweryfikowanymi informacjami.

Po trzecie zaś, wiele wskazuje na to, iż przyzwolenie społeczne, skala zjawiska, ale i coraz szersze grono coraz bardziej znaczących aktorów, będą ośmielały zwiększającą się liczbę polityków do stosowania podobnych praktyk. Wskazuje na to także ich coraz częstsza obecność w komunikacji publicznej (obecnej np. na stronach internetowych urzędów, administracji, organów państwowych itp.). Wydaje się to o tyle symptomatyczne, iż opisywane tu prawidłowości przenoszone są na inny poziom ich uwiarygodniania: z przestrzeni prywatnej na publiczna, legitymizowaną przez państwo.

Wiele przykładów świadczy o powiększającej się skali tego zjawiska, jak chociażby ten, kiedy po oficjalnym objęciu prezydentury przez Donalda Trumpa, prócz licznych zmian na oficjalnej stronie Białego Domu odzwierciedlających linię programową administracji nowej głowy państwa, pojawiły się także informacje nieprawdziwe, które stanowić miały argument w dyskusji nad zaostrzeniem prawa (zob. rys. 1).

The Trump Administration is committed to reducing violent crime. In 2015, homicides increased by $17 \%$ in America's fifty largest cities. That's the largest increase in 25 years. In our nation's capital, killings have risen by 50 percent. There were thousands of shootings in Chicago last year alone.

Rys. 1. Zrzut z ekranu fragmentu strategii zmian w prawie na stronie internetowej Białego Domu

Źródlo: https://www.whitehouse.gov/, 21.01.2017 r.

Znowuż, nie twierdzimy, iż jest to zjawisko nowe, a stosowanie nieprawdy z wykorzystaniem oficjalnych państwowych kanałów informacyjnych jest domeną li tylko ostatnich lat w zachodnich demokracjach

7 Trudno skądinąd dziwić się temu zjawisku, skoro podstawową miarą sukcesu marketingowego kampanii jest jej różnie rozumiana skuteczność. (Zięba, 2010, s. 278-287). 
liberalnych. Wskazane jednak przez nas: skala zjawiska, zaniechanie sprostowań, zastąpienie przyznania się do winy retorycznymi grami oraz systemowe i zorganizowane stosowanie nieprawdy mogą świadczyć o pojawieniu się problemu w nowych, nieznanych dotąd rozmiarach. Jeśli zjawisko to doprowadzi do zobojętnienia obywateli w krajach demokratycznych, braku wrażliwości na nieprawdę, jak i chęci do poszukiwania wiarygodnych źródeł informacji (co zdaje się stopniowo narastać), to może się to okazać zgubne dla samej stabilności systemu, opartego (naiwnie?) o zasady takie jak: wzajemne zaufanie, działanie w dobrej wierze i mechanizmy kontroli władzy.

\section{Wnioski}

Intencjonalne posługiwanie się kłamstwem, jego językowa waloryzacja i włączenie nieprawdy w sekwencje działań strategicznych nastawionych na określony cel polityczny zdają się wykraczać poza standardową aktywność marketingową rozumianą bezprzymiotnikowo. Istnieje bowiem zasadnicza różnica między akcentowaniem pozytywnych cech, zmianami wizerunkowymi czy nawet nieeksponowaniem pewnych mankamentów produktu, a świadomym wprowadzaniem klientów czy opinii publicznej w błąd dla osiągnięcia określonej korzyści. Czytelny podział na tożsamy dla demokracji marketing polityczny i przynależną autorytaryzmom propagandę, zdaje się zacierać w obliczu upodobnienia się metod i środków w realizacji politycznych celów. Warto fakt ten wpisać w szerszą perspektywę badań nad kryzysem demokracji liberalnej, próbując odnaleźć przyczynę/skutek jej osłabienia na poziomie mediów.

Te bowiem, jak pokazuje praktyka działań marketingowych w obszarze polityki, odgrywają kluczową rolę w dystrybucji postprawdy. Dotyczy to zarówno mediów tradycyjnych (Tallis, 2016, s. 10), jak i znacznie lepiej dostosowanych do tego serwisów społecznościowych. To one, jak się wydaje, odgrywają kluczową rolę w tym procederze, także dzięki swojej specyfice i ,genetycznemu przystosowaniu” do emitowania niezweryfikowanych treści. Fakt ten zdaje się tym bardziej symptomatyczny, iż to właśnie one stanowić miały w rozważaniach z początku wieku nową nadzieję na rozwiązanie problemów demokracji m.in. tych dotyczących niskiej partycypacji, nikłego włączania się obywateli w dyskusję, czy braku odpowiednich narzędzi kontroli władzy przez media. Tymczasem okazało się, iż uspołeczniona sieć staje się 
źródłem kolejnych problemów, spośród których dystrybucja postpraw$d y$ zdaje się być jednym z najniebezpieczniejszych.

\section{Bibliografia}

Arendt H. (1985), Prawda a polityka, „Literatura na świecie”, nr 6.

Borudsiak B., Pierański B., Romanowski R., Strykowski S. (2015), Automatyzacja personalizacji reklamy internetowej, „Marketing w praktyce”, $\mathrm{nr} 3$.

Chudy W. (2003), Filozofia kłamstwa. Kłamstwo jako fenomen zła w świecie osób i społeczeństw, Warszawa.

Chudy W. (2003), Kłamstwo, w: Encyklopedia Pedagogiczna XXI Wieku, t. 2, red. E. Różycka, Warszawa.

Chudy W. (1990), Kłamstwo korupcja prawdy, człowieka i społeczeństwa, „Przegląd Powszechny", nr 6.

Chudy W. (2003), Kłamstwo społeczne i jego skutki, w: Blad antropologiczny, red. A. Maryniarczyk, K. Stępień, Lublin.

Festinger L. (1957), A Theory of Cognitive Dissonance, Stanford.

Filipowicz M. (2016), Kłamstwo jako zagrożenie wspótczesnego spoteczeństwa, „Interdyscyplinarne Studia Społeczne", nr 1.

Flood A., 'Post-truth' named word of the year by Oxford Dictionaries, „The Guardian", https://www.theguardian.com/books/2016/nov/15/post-truth-namedword-of-the-year-by-oxford-dictionaries.

Higgins K. (2016), Post-truth: a guide for the perplexed, „Nature”, nr 9 (540).

Jeran A. (2008), Plotka zawsze realna (i zawsze wirtualna) - o różnicach i podobieństwach $w$ plotkowaniu $w$ świecie realnym $i$ wirtualnym, w: Komunikacja spoteczna w świecie wirtualnym, red. M. Wawrzak-Chodaczek, Torun.

Juza M. (2013), Memy internetowe - tworzenie, rozpowszechnianie, znaczenie spoteczne, „Studia Medioznawcze”, nr 4 (55).

Keyes R. (2004), The Post-Truth Era: Dishonesty and Deception in Contemporary Life, New York.

Kreft J. (2016), Schyłek tradycyjnego dziennikarstwa prasowego a nowa logika mediów, „Zeszyty Prasoznawcze”, nr 2 (226).

Lockie S. (2017), Post-truth politics and the social sciences, „Environmental Sociology", nr 3.

Pawełczyk P. (2000), Socjotechniczne aspekty gry politycznej, Poznań.

Pawłowski Ł. (2016), Prawda się kończy, także u nas. (Polemika z Dariuszem Rosiakiem), ,Kultura Liberalna”, nr 416 (52), http://kulturaliberalna.p1/2016/12/28/ pawlowski-rosiak-post-prawda-kaczynski-polemika/.

Post-truth, https://www.oxforddictionaries.com/press/news/2016/12/11/WOTY-16.

Segmentacja, targeting, pozycjonowanie na rynku politycznym (2014), red. M. Cichosz, D. Skrzypiński, Wrocław. 
„Stare” $i$,nowe” media w kontekście kampanii politycznych $i$ sprawowania władzy (2010), red. M. du Vall, A. Walecka-Rynduch, Kraków.

Stone P., Data firm in talks for role in White House messaging - and Trump business, https://www.theguardian.com/us-news/2016/nov/23/donald-trumpcambridge-analytica-steve-bannon.

Suiter J. (2016), Post-Truth Politics, „Political Insight”.

Tallis B. (2016), Living in Post-truth: Power/Knowledge/Responsibility, „New Perspectives Interdisciplinary Journal of Central \& East European Politics and International Relations", nr 10 (24).

Wnuk-Lipiński E. (1992), Fatszywe świadectwo w życiu publicznym, „Więź”, nr 1.

Zięba K. (2010), Skuteczność działań marketingowych, „Zeszyty Naukowe. Polityki Europejskie, Finanse i Marketing", nr 3 (52).

Post-truth and the new media. Do we need post-truth?

\section{Summary}

Post-truth was acknowledged as the word of 2016 by the editors of the Oxford Dictionaries. Several months ago it was a fashionable term used by intellectuals and scholars in the social sciences to offer a better or worse description of the reality of the Western world and the quite unexpected collapse of its order. Today, post-truth is successfully employed in everyday speech by columnists, journalists and even satirists. Given this rapid popularity of post-truth, it is worth asking the question of whether a new term is required to complement the conceptual apparatus of political science, and if such a term can make any contribution to studies into the political reality, particularly when such events as Brexit or the election of Donald Trump as the $45^{\text {th }}$ US President are taken into account. The purpose of this paper is therefore to answer the question of the extent to which post-truth is conceptually autonomous. Another question concerns the dissemination of false information and the participation of new media in this process.

Key words: post-truth, new media, political marketing 